\title{
PROSES PUBLIC RELATIONS PT. KERETA API INDONESIA (PERSERO) DALAM MEMBANGUN CITRA POSITIF MELALUI MEDIA SOSIAL INSTAGRAM @KERETAAPIKITA
}

\author{
Nadia Zulfa Nur Azizah', Ayub Ilfandy Imran² \\ 1,2 Jurusan Ilmu Komunikasi, Fakultas Komunikasi dan Bisnis, Universitas Telkom \\ Email coresponding author: nadiazulfana@gmail.com, a_ilfandy@yahoo.com
}

\begin{abstract}
Abstrak
Dewasa ini muncul banyak akun-akun Instagram perusahaan termasuk perusahaan jasa transportasi di Indonesia sebagai salah satu cara untuk melakukan fungsi public relations, salah satu perusahaan jasa tersebut adalah PT. Kereta Api Indonesia (Persero). Walau menjadi satu-satunya perusahaan perkeretaapian di Indonesia, namun PT. Kereta Api Indonesia (Persero) harus tetap melakukan public relations demi menjaga hubungan dengan masyarakat dan membangun citra positif perusahaan. Salah satu cara yang dilakukan oleh PT. Kereta Api Indonesia (Persero) adalah pengelolaan akun resmi Instagram yaitu @keretaapikita. Maka dari itu, penelitian ini dilatarbelakangi oleh pentingnya perusahaan untuk melakukan public relations guna menjaga hubungan dengan masyarakat serta membangun citra perusahaan. Objek penelitian ini adalah proses public relations akun resmi Instagram @keretaapikita yang unik dan tentu saja berbeda dengan akun-akun Instagram perusahaan jasa transportasi lainnya. Teori dan konsep yang digunakan dalam penelitian ini yaitu konsep public relations, proses public relations, dan citra. Penelitian ini dilaksanakan dengan menggunakan pendekatan kualitatif deskriptif. Hasil penelitian ini menunjukan bahwa unit Public Relations PT. Kereta Api Indonesia (Persero) melakukan semua proses public relations seperti fact finding, planning, communicating, dan evaluating dalam mengelola akun Instagram @keretaapikita dengan mengemas konten yang menarik sehingga dapat membuat citra positif perusahaan di mata masyarakat.
\end{abstract}

Kata Kunci: Public Relations, Proses Public Relations, Citra, Instagram.

\begin{abstract}
Nowadays, lot of official Instagram's accounts from companies especially in the transportation industry appears to acquire some functions of public relations, one of the company is PT. Kereta Api Indonesia (Persero). Although the only one railway company in indonesia, but PT. Kereta Api Indonesia (Persero) have to perform public relations activity to keep good relations with all of their stakeholders and to maintain their good image. One of the activities from PT. Kereta Api Indonesia (Persero) is to manage @keretaapikita which is an official Instagram account. This research is based on the importance of company to implement a public relations activity to keep good relations with all of their stakeholders and also to keep the company's good image. The object of this research is public relations process from @keretaapikita which has uniqueness and several differentiation from the others official company account. Theories which will be used in this research are public relation concept, public relation process, and image. This research employs descriptive qualitative research design. These results indicate that Public Relations unit in PT. Kereta Api Indonesia (Persero) has done the all public relations processes such as fact finding, planning, communicating, and evaluating in managing Instagram account of @keretaapikita with an attractive packaging content so that it can create a positive image in the public eye.
\end{abstract}

Keywords: Public Relations, Public Relations Process, images, Instagram.

\section{PENDAHULUAN}

Dalam era globalisasi seperti saat ini, teknologi informasi dan komunikasi berkembang dan mempengaruhi kehidupan masyarakat, termasuk dalam kegiatan public relations. Saat ini public relations memanfaatkan perkembangan teknologi informasi seperti media sosial untuk berkomunikasi dengan masyarakat. Penggunaan media sosial dalam kegiatan public relations dilakukan karena 
dengan media sosial dapat terjadi komunikasi dua arah antara organisasi atau perusahaan dengan masyarakat. Hal ini membuat media sosial menjadi salah satu media yang digunakan perusahaan untuk melakukan proses public relatinnya. Kegiatan public relations penting dilakukan oleh perusahaan guna menjalin hubungan yang baik serta menciptakan citra positif di mata masyarakat. Saat ini kegiatan public relations dapat dilakukan dengan banyak cara salah satunya lewat media sosial.

Salah satu perusahaan yang menggunakan media sosial dalam kegiatan public relations untuk membangun citra perusahaan adalah PT. Kereta Api Indonesia (Persero), yaitu perusahaan yang bergerak dalam bidang transportasi khususnya perkeretaapian. Walaupun menjadi satu-satunya perusahaan perkeretaapian di Indonesia, PT. Kereta Api Indonesia (Persero) tetap melakukan aktivitas public relations. Salah satu media sosial yang digunakan oleh PT. Kereta Api Persero dalam melakukan public relations adalah akun Instagram yang memiliki nama @keretaapikita. Akun Instagram @keretaapikita memiliki 336.000 pengikut. Melalui akun Instagram tersebut PT. Kereta Api Indonesia (Persero) membagikan berbagai informasi kepada masyarakat tentang PT. Kereta Api Indonesia (Persero) tentang kegiatan perkeretaapian dan hal lainnya baik itu melalui tulisan, foto, maupun video. Dengan adanya akun Instagram @keretaapikita, masyarakat dapat mengakses dan mencari tahu hal mengenai perkeretaapian serta kegiatan-kegaiatan yang sedang dilakukan oleh PT. Kereta Api Indonesia (Persero).

Berdasarkan beberapa ketertarikan yang telah diungkapkan oleh peneliti sebelumnya, peneliti hendak mengangkat penelitian dengan judul "Proses Public Relations PT. Kereta Api Indonesia (Persero) dalam Mengelola Akun Instagram @keretapikita”.

\section{TINJAUAN PUSTAKA}

\section{Public Relations}

Menurut British Institute of Public Relations dalam buku Jefkins (2003:9), public relations adalah usaha yang dilakukan dengan terencana untuk menciptakan dan memelihara niat baik (goodwill) dan saling pengertian antara organisasi dengan publiknya. Sedangkan Ruslan (2005:8) menyimpulkan bahwa Public relations adalah kegiatan yang dilakukan untuk mendapatkan goodwill, terciptanya kepercayaan, saling pengertian, dan membentuk citra baik dari masyarakat. Selain itu, public relations adalah salah satu unsur yang penting untuk mendukung organiasi atau perusahaan untuk mencapai tujuan serta usaha yang dilakukan untuk menciptakan hubungan harmonis antara organisasi dengan masyarakat melalui komunikasi timbal-balik, hubungan yang harmonis, saling percaya, dan menumbuhkan citra positif.

Bersadarkan beberapa definisi teori diatas, peneliti mengambil kesimpulan bahwa public relations adalah kegiatan yang dilakukan terstruktur dan terencana dari salah satu fungsi manajemen sebagai jembatan antara organisasi atau perusahaan dengan publiknya baik itu publik internal maupun eksternal. Public relations memiliki fungsi untuk menjaga hubungan baik dengan publiknya. Selain itu public relations mempunyai peran untuk membentuk dan menumbuhkan citra yang positif bagi organisasi atau perusahaan di mata publiknya.

Selain berfungsi untuk menciptakan citra yang positif bagi organisasi atau perusahaan, public relations mempunyai fungsi seperti yang terdapat dalam Al-Firdaus (2013:28), yaitu: (1) Menarik simpati masyarakat agar organisasi atau perusahaan dapat dikenal oleh publik dengan baik, atau dapat disebut dengan tindakan pencitraan; (2) Memberi tahu kepada maysrakat tentang fungsi kelembagaan dan keuntungan yang akan diperoleh masyarakat jika bergabung dengan organisasi atau menggunakan jasa dari perusahaan tersebut; (3) Menimbulkan efek persuasif atau membujuk secara langsung sehingga masyarakat mengbah sikapnya dari yang sebelumnya belum percaya menjadi 
percaya terhadap organisasi atau perusahaan; (4) Menjadi media penguhubung antara masyarakat sebagai pelanggan dari perushaan dengan manajemen sebagai penyedia jasa dan layanan.

Selain memiliki fungsi, public relations juga memiliki aktvitas. Aktivitas public relations adalah kegiatan untuk mendukung tercapainya tujuan perusahaan serta menciptakan dan mempertahankan identitas dan citra perusahaan. Menurut Ruslan (1999:4) aktivitas public relations terdiri dari: (1) Membangun Identitas dan Citra Perusahaan. Sebagai public relations tentunya hadus mampu untuk menciptakan identitas dan citra perusahaan yang positif di mata publik. Selain itu, public relations juga harus mendukung kegiatan komunikasi dua arah atau timbal balik dengan publik; (2) Menghadapi Krisis. Public relarions mempiliki tugas untuk menangani keluhan dari publik dan menghadapi krisis yang terjadi pada organisasi atau perusahaan untuk mempebaiki citra organisasi atau perusahaan yang sedang tidak baik agar dapat kembali menjadi baik dimata publik.

\section{Proses Public Relations}

Dalam melaksanakan aktivitas public relations tentu saja kita membutuhkan tahapan agar dapat mencapai hasil yang diinginkan serta berjalan dengan efektif. Tahapan tersebut biasanya disebut dengan proses public relations, seperti yang dikemukakan Cutlip, Centre, dan Broom (2005:268), proses public relations terdiri dari: (1) Fact Finding. Tahap fact finding adalah tahap pengumpulan data untuk mengetahui opini, perilaku, sikap, dan pemahaman masyarakat terhadap perusahaan. Dalam tahapan fact finding, praktisi public relations biasanya melakukan hal-hal seperti memperhatikan kejadian atau perkembangan sosial, politik, dan ekonomi yang secara langsung maupun tidak langsung dapat mempengaruhi perusahaan, mengumpulkan berbagai data yang sesuai fakta untuk diolah menjadi sebuah informasi, menganalisa informasi tersebut agar sesuai dengan keperluan perusahaan, selalu siap sedia untuk menyajikan informasi kepada setiap unit di perusahaan, menyempurnakan informasi yang masih kurang lengkap dan memadai, menyimpan data-data dan informasi dengan melakukan dokumentasi dan mengkliping semua informasi dari media massa; (2) Planning. Pada tahap planning atau perencanaan, public relations akan merencanakan dan membuat program sesuai dengan yang sudah didapatkan dalam tahap fact fanding. Perencanaan harus sesuai dnegan aturan yang ada serta harus memperhatikan kondisi yang sedang terjadi di dalam maupun di luar perusahaan. Menurut Ruslan dalam jurnal Septian Indra dan Arie Prasetio (2016:2362), tahap planning memiliki 7C sebagai indikator untuk menyusun sebuah rencana, indikator tersebut adalah Credibility, adalah rasa saling percaya antara komunikator dan komunikan. Untuk mendapatkan rasa saling percaya, maka kedua harus menyampaikan informasi sesuai dengan fakta. Context, adalah kesesuaian antara informasi atau pesan dengan kenyataan masyarakat. Content, adalah penggunaan kata saat menyampaikan informasi sesuai dengan target audience. Clarity, adalah pesan yang disampaikan komunikator harus jelas dengan bahasa yang dapat dimengerti. Continuity, adalah penyampaian pesan yang dilakukan berulang-ulang namun bervariasi cara penyampaiannya. Capability, adalah kemampuan komunikator untuk menjelaskan pesan dan dirancang untuk menarik perhatian komunikan biasanya dengan menggunakan simbol, memberi motivasi, dan solusi. Channel, adalah media yang digunakan sebagai saluran penyampaian pesan yang tepat dan efektif; (3) Communicating. Tahap communicating adalah implementasi atau pelaksanaan sesuai dengan data yang telah dirumuskan dalam tahap perencanaan untuk mempengaruhi pandangan masyarakat terhadap perusahaan. Langkah-langkah yang biasanya dilakukan dalam tahap ini adalah merumuskan tujuan atau target yang akan dicapai ketika mengirimkan pesan, mengolah data yang diperoleh, merumuskan dan menyusun cara untuk menyebarkan pesan, memeriksa kelengkapan informasi pada tahap fact finding, menentukan teknik komunikasi, melakukan analisis data dari informasi yang diperoleh serta merumuskan sesuai dengan program kerja perusahaan yaitu sesuai dengan situasi dan kondisi; (4) Evaluating. Tahap evaluating merupakan tahap terakhir untuk melakukan penilaian terhadap apa yang sudah dilakukan dari tahap pertama sampai dengan ke tahap yang terakhir. Penilaian ini dilakukan untuk melihat apakah tujuan dari public relations berhasil atau tidak. Tahap ini juga sebagai bahan evaluasi agar dapat meningkatkan kegiatan public relations selanjutnya. 
Citra adalah gambaran tentang objek yang ada di pikiran masyarakat, Kriyantono (2006:355). Citra dibentuk melalui terpaan stimulus seperti iklan, event, kampanye, dan yang lainnya. Citra terbentuk dari hasil permainan simbol dan asosiasi dan dibangun melalui kesan atau persepsi masyarakat terhadap organisasi atau perusahaan.

\section{New Media}

New media menurut Mondry (2008:13) adalah media yang dalam penggunaanya menggunakan internet, media online berbasis dengan teknologi, interaktif, fleksibel, serta dapat berfungsi secara publik maupun secara privat.

\section{Instagram}

Salah satu media sosial yang saat ini sedang banyak digunakan oleh masyarakat adalah Instagram. Menurut Enterprise (2012: 02), Instagram adalah komunitas yang saling berbagi antara satu anggota dengan anggota yang lainnya dari seluruh dunia

\section{METODE PENELITIAN}

Pada penelitian ini, metode penelitian yang digunakan adalah metode kualitatif dengan pendekatan deskriptif. Menurut Bogdan dan Taylor (1975:5) metode kualitatif adalah prosedur dari sebuah penelitian yang menghasilkan data berupa kata-kata baik itu tertulis ataupun lisan dari orang-orang serta perilaku yang bisa diamati. Selain itu, dalam melakukan penelitian ini, peneliti menggunakan paradigma konstruktivis. Menurut Creswell (2015:32) dalam konstruktivis sosial, individu berusaha untuk memahami dunia tempat mereka hidup dan beraktivitas. Dari pengalaman mereka, maknamakna subjektif akan dikembangkan dan diarahkan pada benda atau objek tertentu. Biasanya peneliti konstruktivis berfokus pada "proses" interaksi yang dilakukan oleh antar individu.

Dalam hal ini subjek dari penelitian ini adalah unit Public Relations PT. Kereta Api Indonesia (Persero). Unit ini dipilih menjadi subjek penelitian karena unit Public Relations mengelola langsung akun Instagram @keretaapikita. Sedangkan objek penelitian dalam penelitian ini adalah proses public relations PT. Kereta Api Indonesia (Persero) melalui Instagram @keretaapikita. Lokasi dalam penelitian ini adalah Kantor Pusat PT. Kereta Api Indonesia (Persero) yang terletak di Jalan Perintis Kemerdekaan No. 1, Bandung. Alasan peneliti memilih lokasi ini karena di kantor PT. Kereta Api Indonesia (Persero) tersebut merupakan tempat dikelolanya akun Instagram @keretaapikita dan di kantor tersebut peneliti bisa bertemu dengan informan. Informan dalam penelitian ini terdiri dari tiga karyawan Unit Public Relations PT. Kereta Api Indonesia (Persero) yang mengelola langsung Instagram @keretaapikita. Penelitian ini dilakukan selama enam bulan, yaitu dari bulan Agustus 2018 sampai dengan bulan Desember 2018. Dalam penelitian ini, pengumpulan data dilakukan dengan melakukan observasi, wawancara, serta dokumentasi. Dalam penelitian ini, peneliti menggunakan teknik triangulasi sumber. Peneliti melakukan wawancara dengan beberapa informan, baik itu informan kunci maupun informan pendukung. Setelah melakukan wawancara, peneliti akan melakukan pengujian antara pemahaman peneliti dengan pemahaman informan dengan cara melakukan uji kredibilitas dan konsistensi data dari hasil wawancara.

\section{HASIL DAN PEMBAHASAN}

\section{Proses Public Relations}

\section{Analisis Tahap Fact Finding Proses Public Relations PT. Kereta Api Indonesia (Persero)}

Unit Public Relations PT. Kereta Api Indonesia (Persero) memiliki empat bagian yaitu Internal Relations, External Relations, Public Informations Care, dan Corporate Image Care. Bagian Corporate 
Image Care melalui sub bagiannya yaitu Web Corporate, BUMN Portal \& Social Media adalah bagian yang mengelola akun media sosial Instagram untuk memberikan informasi kepada masyarakat serta membangun citra perusahaan.

Tujuan munculnya akun Instagram @keretaapikita yaitu untuk membangun citra perusahaan yang baik di mata masyarakat. Hal ini sesuai dengan pernyataan British Institute of Public Relations dalam buku Jefkins (2003:9) bahwa public relations adalah usaha yang dilakukan dengan terencana untuk menciptakan dan memelihara niat baik (goodwill) dan saling pengertian antara organisasi dengan publiknya. Selain itu Ruslan (2005:8) pun menyimpulkan bahwa public relations adalah kegiatan yang dilakukan untuk mendapatkan goodwill, terciptanya kepercayaan, saling pengertian, dan membentuk citra baik dari masyarakat. Sebagai mana seperti tujuan pembuatan akun Instagram @keretaapikita yaitu untuk membangun citra perusahaan.

Seperti yang disampaikan oleh Kriyantono, citra adalah gambaran tentang objek yang ada di pikiran masyarakat (2006:355). Citra dibentuk melalui terpaan stimulus seperti iklan, event, kampanye, dan yang lainnya. Citra terbentuk dari hasil permainan simbol dan asosiasi dan dibangun melalui kesan atau persepsi masyarakat terhadap organisasi atau perusahaan. Hal ini pun dilakukan oleh unit Public Relations PT. Kereta Api Indonesia (Persero) dalam mengelola akun Instagramnnya yang unggahannya berisi tentang informasi event perusahaan, layanan perusahaan, cerita masyarakat saat menggunakan kereta, kuis dan lomba, serta hal lainnya. Kegiatan ini dilakukan untuk menarik simpati masyarakat serta agar masyarakat tetap engange dengan perusahaan. Sejalan seperti apa yang disampaikan dalam Al-Firdaus (2013:28) dimana fungsi public relations adalah untuk menarik simpati masyarakat agar perusahaan dapat dikenal oleh publik dengan baik, atau dapat disebut dengan tindakan pencitraan.

Namun sebelum mengunggah sesuatu pada akun Instagram @keretaapikita, unit Public Relations PT. Kereta Api Indonesia (Persero) mencari data-data dari berbagai sumber seperti berita-berita yang sedang menjadi topik pembicaraan masyarakat, event-event yang dilakukan oleh unit lain, dan fotofoto yang diunggah oleh masyarakat yang sedang menceritakan pengalamannya menggunakan kereta api.

\section{Analisis Tahap Planning Proses Public Relations PT. Kereta Api Indonesia (Persero)}

Agar dapat melakukan pengelolaan dengan baik, unit Public Relations tidak bisa terlepas dari tahap planning atau perencanaan. Sesuai dengan yang dikatakan oleh Cutlip, Center, dan Broom (2005:268) bahwa tahap perencanaan adalah merencanakan dan membuat program sesuai dengan yang sudah didapatkan dalam tahap fact finding. Kemudian dari hasil observasi peneliti dan dihubungkan dengan hasil wawancara peneliti dengan informan, unit Public Relations PT. Kereta Api Indonesa (Persero) melakukan perencanaan dalam mengelola akun Instagram @keretaapikita seperti menentukan terlebih dahulu foto atau video yang akan di unggah di dalam Feeds agar seragam dan rapi. Pemilihan waktu kapan yang tepat untuk menggunggah sesuatu juga penting untuk direncanakan. Akun Instagram @keretaapikita mengunggah foto atau video untuk Feeds Instagramnya dua kali dalam sehari dengan waktu pengunggahan pada pagi serta sore atau malam hari.

Selain itu dalam melakukan perencanaan, terdapat faktor-faktor penting yang diperhatikan seperti momennya harus tepat, informasi yang disampaikan harus benar dan sesuai dengan fakta yang ada, foto atau video yang diunggah menarik, serta caption yang informatif dan menarik. Hal ini sesuai dengan apa yang disampaikan oleh Ruslan dalam jurnal Septian Indra dan Arie Prasetio (2016:2362) dimana pada tahap planning memiliki indikator untuk menyusun sebuah rencana seperti credibility yaitu informasi yang disampaikan harus sesuai dengan fakta, context yaitu informasi yang disampaikan sesuai dengan kenyataan masyarakat, content yaitu penggunaan kata atau caption sesuai dengan target audience, clarity yaitu pesan yang disampaikan harus jelas dengan bahasa yang dapat dimengerti, continuity yaitu penyampaian pesan yang dilakukan berulang-ulang seperti saat mengadakan lomba atau kuis di akun Instagram @keretaapikita dimana akun Instagram 
@keretaapikita mengumumkan lomba video yang dilakukan beberapa kali, capability yaitu kemampuan komunikator untuk menjelaskan pesan, dan yang terakhir channel yaitu media yang digunakan untuk penyampaian pesan.

\section{Analisis Tahap Communicating Proses Public Relations PT. Kereta Api Indonesia (Persero)}

Pada tahap ini, PT. Kereta Api Indonesia (Persero) melakukan communicating atau implementasi dan pelaksanaan sesuai dengan data yang diperoleh dan dirumuskan dalam tahap perencanaan seperti yang disampaikan Cutlip, Center, dan Broom (2005:268). Langkah-langkah yang biasanya dilakukan pada tahap ini adalah mengolah data yang diperoleh, merumusukan dan menyusun cara untuk menyebarkan, memeriksa kelengkapan informasi, dan menentukan teknik komunikasi. Dalam kegiatan ini PT. Kereta Api Indonesia (Persero) memanfaatkan Instagram yang termasuk media online karena bersifat interaktif, fleksibel, serta dapat berfungsi secara publik maupun secara privat seperti yang disampaikan oleh Mondry (2008:13) tentang media online yaitu media yang dalam penggunaanya menggunakan internet, media online berbasis dengan teknologi, interaktif, fleksibel, serta dapat berfungsi secara publik maupun secara privat.

Akun Instagram @keretaapikita melakukan tahap communicating dengan menggunggah sesuatu seperti foto dan video dengan memanfaatkan fitur-fitur yang di Instagram seperti Feeds, Instastory, Live, dan IG TV. Selain itu informasi yang disampaikan melalui akun Instagram @keretaapikita berisi tentang event perusahaan, layanan perusahaan, foto produk, serta tak jarang akun Instagram @keretaapikita mengadakan kuis dan lomba untuk meningkatkan engagement masyarakat. Tidak lupa akun Instagram @keretaapikita juga membalas komentar masyarakat pada kolom komentar yang tersedia dalam akun Instagram tersebut. Kegiatan-kegiatan tersebut adalah contoh aktivitas public relations karena bertujuan untuk membangun identitas dan citra perusahaan seperti yang dikemukakan oleh Ruslan (1999:4).

\section{Analisis Tahap Evaluating Proses Public Relations PT. Kereta Api Indonesia (Persero)}

Pada tahap ini, unit Public Relations PT. Kereta Api Indonesia (Persero) melakukan tahap evaluating atau pengawasan dengan berpedoman pada pengertian evaluating menurut Cutlip, Center, dan Broom (2005:268) yaitu tahap terakhir untuk melakukan penilaian terhadap apa yang sudah dilakukan dari tahap pertama sampai dengan ke tahap yang terakhir. Penilaian ini dilakukan untuk melihat apakah tujuan dari public relations berhasil atau tidak. Tahap ini juga sebagai bahan evaluasi agar dapat meningkatkan kegiatan public relations selanjutnya.

Evaluasi dalam unit Public Relations dilakukan bermacam waktu, mulai yang bersifat tidak rutin seperti saat setelah selesai melakukan peliputan event perusahaan, maupun yang bersifat rutin seperti evaluasi tentang konten apa yang menarik dan menjadi ramai diperbicangkan masyarakat saat diunggah, dan juga dilakukan perekapan banyaknya likes, comment, dan peningkatan followers yang dikakukan tiap bulan dan tiap semester. Selain itu solusi yang dilakukan setelah melakukan evaluasi adalah dengan mencari topik-topik atau berita lain yang dapat menambah wawasan sehingga dapat dijakan menjadi konten unggahan. Selain itu, jika ditemukan masyarakat yang mengadukan masalahnya di kolom komentar akan disambungkan ke bagian customer care khusus yang memang tugasnya untuk melayani keluhan masyarakat.

Selain itu, untuk mengukur pencapaian citra, citra positif diukur dengan menggunakan prosentase Engagement rate atau jumlah interaksi terhadap konten akun yang dikelola. Dengan prosentase Engagement rate yang memenuhi target yang ditetapkan pada Key Performance Indikator (KPI), bisa dikatakan bahwa keterlibatan atau interaksi antara Instagram @keretaapikita sebagai pengirim pesan kepada penerima pesan termasuk dalam kategori sesuai dengan yang diharapkan. Sehingga semua pesan positif mengenai perusahaan dapat tersampaikan dengan baik. Di tahun 2018, KAI menetapkan KPI untuk Instagram @keretaapikita adalah Engagement rate nya mencapai 3\%. Angka ini termasuk pada kategori average/good Engagement Rate yang berkisar di antara 1\%-3.5\%. Engagement Rate 
tersebut terbentuk dari beberapa komponen diantaranya followers, post, reach, impression, like, comment, dan save. Dapat pula disimpulkan bahwa audience memiliki ketertarikan terhadap pesan yang dikirim melalui IG @keretaapikita. Followers IG @keretaapikita pada akhir tahun 2018 berada di angka 345.587. Dengan jumlah followers yang terus tumbuh tentu media sosial ini dapat digunakan untuk membangun citra positif perusahaan.

\section{SIMPULAN}

Dalam penelitian ini, proses public relations yang dilakukan oleh unit Public Relations dalam mengelola akun Instagram @keretaapikita adalah sebagai berikut:

\section{Fact Finding}

Fact findung adalah kegiatan pengumpulan data dan sumber sebelum dijadikan informasi yang akan disampaikan untuk masyarakat. Dalam tahap ini, akun Instagram @keretaapikita melakukan tahap fact finding sebagai bahan yang nantinya akan menjadi sebuah informasi yang akan disamapikan kepada masyarakar. Tahap fact finding yang dilakukan oleh unit Public Relations dalam mengelola akun Instagram @keretaapikita adalah dengan mencari berbagai macam berita di media massa yang sedang hangat dibicarakan oleh masyarakat. Selain itu data informasi juga diperoeh dari unit-unit terkait yang mempunyai kegiatan yang harus dipublish oleh unit Public Relations melalui akun Instagramnya.

\section{Planning}

Planning atau perencanaan adalah tahapan perusahaan menentukan dan merencanakan program sesuai dengan yang sudah didapatkan dalam tahap fact finding. Pada umumnya, perencanaan dilakukan oleh perusahaan untuk memenuhi tujuan dari perusahaan itu sendiri serta agar dlam pelaksanaan kegiatan dapat berjalan lebih teratur. Dalam tahap ini akun Instagram @keretaapikita telah melakukan tahap perencanaan dalam mengelola akun Instagramnya. Perencanaan yang dilakukan adalah berupa menentukan konten yang akan diunggah, menentukan waktu yang tepat kapan konten diunggah, serta pengemasan informasi yang disampaikan termasuk dalam penulisan caption. Untuk jadwal mengunggah konten, akun Instagram @keretaapikita setiap harinya selalu mengunggah konten di dalam akun Instagramnya. Biasanya waktu untuk menggunggah feeds adalah pagi hari dan sore hari. Kemudian untuk instastory menyesuaikan dengan instastory yang dikirimkan oleh masyarakat atau menyesuaikan dengan informasi yang didapatkan. Sedangkan untuk live dan $I G$ $T V$ biasanya dilakukaan saat ada acara tertentu.

\section{Communicating}

Communicating adalah implementasi atau pelaksanaan dari kegiatan komunikasi yang dilakukan. Seperti halnya pada unit Public Relations yang melaksanakan tahap communicating dengan menggunggah konten dan memanfaatkan beberapa fitur-fitur yang ada di Insagram seperti feeds, instastory, live, dan IG TV. Selain memanfaatkan fitur-fitur yang ada, komunikasi yang dilakukan oleh akun Instagram @keretaapikita adalah dengan mengadakan kuis dan lomba untuk meningkatkan engagement masyarakat. Dalam melakukan komunikasi, unit Public Relations memperhatikan beberapa hal seperti waktu pengunggahan, informasi yang disampaikan harus sesuai dnegan fakta, gambar dan video yang ditampilkan harus bagus, serta penulisan caption yang menarik dan dapat menimbulkan respon baik masyarakat. Selain itu dalam akun Instaramnnya pun, unit Public Relations membalas beberapa komentar masyarakat di kolom komentar.

\section{Evaluating}

Evaluating adalah melakukan penilaian dari apa yang sudah dilakukan dari tahap pertama sampai dengan tahap terakhir. Penilaian ini dilakukan untuk melihat apakah tujuan dari public relations 
berhasil atau tidak. Tahap ini juga sebagai bahan evaluasi agar dapat meningkatkan kegiatan public relations selanjutnya. Unit Public Relations PT. Kereta Api Indonesia (Persero) juga mengadakan evaluasi dalam mengelola akun Instagram @keretaapikita. Evaluasi yang dilakukan adalah evaluasi terhadap konten yang diunggah, melihat konten apakah yang ramai dibicarakan oleh masyarakat, serta merekap jumlah followers, likes, comments yang ada di akun Instagram @keretaapikita tiap bulannya. Solusi yang dilakukan setelah melakukan evaluasi adalah dengan memperbanyak pencarian berita-berita yang sedang hangat dibicarakan masyarakat agar nantinya akun Instagram @keretapikita dapat menyajikan konten yang menarik. Namun untuk masalah keluhan masyarakat, unit Public Relations langsung meneruskan keluhan masyarakat tersebut ke bagian Custumer Care.

\section{DAFTAR PUSTAKA}

Al-Firdaus, Iqra'. 2013. Kiat Hebat Public Relations Ala Nabi Muhammas SAW. Yogyakarta: Najah

Andi Refandi Febriyansyah, Maylanny Christin, dan Ayub Ilfandy Imran (2016). Strategi Media Relations PT. Pelabuhan Tanjung Priok dalam Menggapi Krisis. Jurnal Kajian Komunikasi, Volume 4, (Nomor 2), Halaman 229-241.

Bogdan, R. and Taylor, S.J. 1975. Introduction to Qualitative Research Methode. New York: John Willey and Sons.

Creswell, John W. 2015. Penelitian Kualitatif \& Desain Riset. Yogyakarta: Pustaka Pelajar.

Cutlip, Scoot M., Allen H. Center, dan Glen M. Broom. 2005. Effective Public Relations. Jakarta: PT. INDEKS Kelompok Gramedia.

Enterprise, Jubilee. 2012. Instagram untuk Fotografi Digital dan Bisnis Kreatif. Jakarta: PT Alex Media Komputindo.

Fitri Afrilia, Martha Tri Lestari, S.Sos., MM, dan Dini Salmiyah Fithrah Ali, SS., M.Si (2015) Proses Public Relations Dalam Mengelola Media Sosial Twitter (Studi Deskriptif Pada Program Public Relations @infobdg Periode Mei 2015). E-Proceeding of Management, Volume 2, (Nomor 3), Halaman 43374434 .

Jefkins, Frank. 2003. Public Relations, terj Daniel Yadin. Jakarta: Erlangga.

Kriyantono, Rachmat.2006. Teknik Praktis Riset Komunikasi. Jakarta: Kencana.

Mondry. 2008. Pemahaman Teori dan Praktek Jurnalistik. Bogor: Ghalia Indonesia

Naraya Mahendra Prastya (2013). Media Sosial dan Peran Manajerial Public Relations PT PLN Persero. Jurnal Ilmu Komunikasi, Volume 10, (Nomor 2), Halaman 159-178.

Nurahma Kuntum Rahdiani dan M. Subur Drajat (2017). Aktivitas Humas PT. Kereta Api Indonesia (Persero) dalam Menjalankan Media Internal E-Office. Prosiding Hubungan Masyarakat, Volume 3, (Nomor 2), Halaman 444-450.

Ruslan, Rosady. 1999. Praktik dan Solusi Public Relations Dalam Situasi Krisis dan Pemulihan Citra. Jakarta: Ghalia Indonesia.

Ruslan, Rosady. 2005. Kiat dan Strategi Kampanye Public Relations. Jakarta:,PT Raja Grafindo Persada.

Septian Indra Kusuma dan Arie Prasetio, Sos., M.Si (2016). Proses Public Relations PT. Pos Indonesia dalam Mempertahankan Citra Terkait Beredarnya Tabloid Obor Rakyat. E-Proceeding of Management, Volume 3, (Nomor 2), Halaman 2359-2368. 